\title{
The Disparities on Loss of Employment Income by US Households During the COVID-19 Pandemic
}

\author{
Okechukwu D. Anyamele ${ }^{1} \cdot$ Saundra M. McFarland ${ }^{1} \cdot$ Kenneth Fiakofi $^{1}$
}

Received: 6 February 2021 / Revised: 22 June 2021 / Accepted: 28 June 2021 / Published online: 15 July 2021

(c) The Author(s), under exclusive licence to Springer Nature Switzerland AG 2021

\begin{abstract}
This paper examines the role of the COVID-19 pandemic on the loss of employment income on different ethnic groups in the USA using weekly Household Pulse Survey (HPS) data from the US Census Bureau from August 19 to November 9, 2020. This study is significant for two reasons. First, it documents the loss of employment income on various households in the USA during the COVID-19 pandemic period from March 13, 2020, to November 9, 2020. Second, it examines the effect on the different ethnic groups based on demographic and socioeconomic status of these households. We specifically examine the role of income, employment, education, location, access to technology, and health insurance among the different age groups, race/ethnicity, and gender. We employ multivariate logistic regression analysis for the study. The study also employs Oaxaca-Blinder decomposition analysis to investigate the source of disparities in loss of employment income on the different racial/ethnic groups. The multivariate regression examines the effects of income, employment, education, location, health insurance, access to technology, different age groups, race/ethnicity, and gender. This method enables us to estimate the level of differences in loss of employment income outcomes among the various race/ethnic groups based on their socioeconomic status. Our a priori expectation is that loss of employment income and household income, educational status, and employment will be positively correlated. However, we have no a priori expectation of the correlation with location, race/ ethnicity, and gender. Our results show that Hispanics, Blacks, Other, and Asians experienced a loss of employment income of $35.6 \%, 25.3 \%, 31.2 \%$, and $6.2 \%$ higher than Whites, respectively. Equally important is that $45.9 \%, 40.3 \%$, and $25.2 \%$ of the differences are unexplained or attributed to discrimination for Hispanics, Other, and Blacks, respectively.
\end{abstract}

Keywords Loss of employment income $\cdot$ Race/ethnicity $\cdot$ Health status $\cdot$ Health insurance $\cdot$ Access to Technology . Household Pulse Survey

JEL Classification D12 $\cdot$ G5 $\cdot$ J15

\section{Introduction}

One of the lasting impacts of the novel coronavirus disease of 2019 (COVID-19) pandemic is the exposure of the level of socioeconomic inequality in American society. Although past studies have highlighted the level of inequality in American society, this COVID-19 pandemic has proven to be a proximate catalyst in laying bare the extent of disparity in socioeconomic status and income among the different ethnic

Okechukwu D. Anyamele

Okechukwu.d.anyamele@jsums.edu

1 Department of Business, College of Business, Jackson State University, 1400 J.R. Lynch Street, Jackson, MS 39217, USA groups in America. This inequality has manifested in the rate of mortality from the COVID-19 pandemic among the different ethnic groups.

Oaxaca-Blinder decomposition results show that highly significant differences exist in loss of employment income between the different race/ethnic groups during the COVID19 pandemic. Blacks experienced a mean loss of employment income of -0.0945 than the mean loss of employment income of all the other ethnic groups. "Other race," mainly Hispanics, experienced a mean loss of employment income of -0.106 than the mean loss of employment income of all the other ethnic groups. What is even more telling is the portion of this loss of employment income explained by differences in endowments. For Blacks, $73.33 \%$ of the difference in a mean loss of employment income is explained 
by differences in endowments. The figure for "Other race" is $59.06 \%$.

For Blacks, $43.87 \%$ of this difference comes from differences in income, $24.82 \%$ comes from differences from health insurance, $17.89 \%$ comes from differences in health, while differences in education accounted for $12.28 \%$ of these differences in endowments. A look at "Other race" shows a similar pattern, albeit slightly different. Health insurance accounted for about $30.83 \%$ of the difference in endowments. $29.87 \%$ of the difference in endowments came from income, computer explained $22.20 \%$ of the difference in endowments between "Other race" and the rest of the ethnic groups. $17.41 \%$ of the difference came from health, and education accounted for $16.45 \%$ of the difference in endowments. These results highlight entrenched differences in endowments among the ethnic groups in income, health insurance, health, education, and technology in the USA.

According to the Center for Disease Control (CDC) Morbidity and Mortality Weekly Report, October 23, 2020, Vol. 69 No. 42 between May and August 2020, Whites accounted for $51.3 \%$ of COVID-19 deaths in the USA while Hispanics or Latinos constituted 24.2\%, Blacks 18.7\%, and Asians $3.5 \%$ of the deaths in the USA, respectively. According to a survey conducted by National Public Radio (NPR), Robert Wood Johnson Foundation, and Harvard University School of Public Health between July 1 and August 3, 2020, 72\% of Latino households reported facing severe financial problems during the coronavirus outbreak. Sixty percent of Black households reported facing serious financial problems during the coronavirus outbreak. Fifty-five percent of Native American households reported facing serious financial problems during the coronavirus outbreak. For Asian households, only $37 \%$ reported facing serious financial problems during the coronavirus outbreak. Similarly, only $36 \%$ of White households reported facing serious financial problems during the coronavirus outbreak. A Congressional Research Service report of November 9, 2020, found that the largest proportion of households that lost employment income were those with children and low incomes $(65 \%$ of households with 2019 incomes below $\$ 25,000$ and children lost some employment income since March); households without children and with a respondent aged 65 and over were the least likely to lose employment income. Specifically, Hispanics (Any Race) experienced the highest rate of lost employment income of 58\%; this was followed by Other race of 54\%, Black 51\%, Asian 47\%, and White $41 \%$.

While the focus of our study is not on the mortality rate from the COVID-19 pandemic, it is equally important to show that Whites constitute $76.3 \%$ of the US population but only account for $51.3 \%$ of COVID-19 pandemic deaths. Blacks account for $13.4 \%$ of the US population but accounted for $18.7 \%$ of COVID-19 pandemic deaths, while Hispanics make up $18.5 \%$ of the population but account for $24.2 \%$ of COVID-19 pandemic deaths. Asians make up $5.9 \%$ of the US population. However, they only account for $3.5 \%$ of COVID-19 pandemic deaths. Again, the disparity is evident even in the CDC data. Regarding the geographic location of deaths in America, $45.7 \%$ occurred in the South, $20.5 \%$ in the Northeast, $18.3 \%$ in the West, and $15.5 \%$ in the Midwest.

We focus on the impact of the loss of employment income and expected loss of employment income on US households to show the disparity of the COVID-19 pandemic on the socioeconomic status of the various ethnic groups. Black households account for $15.4 \%$ of the loss of employment income, while the loss of employment income for Asian households is $5.12 \%$, Other races $6.86 \%$, and Whites $72.64 \%$ based on the Household Pulse Survey data. Education, health, income, marital status, access to a computer, access to the Internet, and location are some of the variables used to understand the impact of the loss of employment income on US households over this COVID-19 pandemic. We must understand the sources of disparities among the different ethnic groups to enable us to design policies that will help ameliorate the impact of the COVID-19 pandemic. To do this, we apply the Oaxaca-Blinder decomposition analysis to further help us pin down the sources of these disparities on the loss of employment income and expected loss of employment income among the ethnic groups.

\section{Literature Review}

There was the emergence of two major coronavirus (CoVs) epidemics before the deadly COVID-19 pandemic. The severe acute respiratory syndrome coronavirus (SARS$\mathrm{CoV}$ ) of 2002 had spread to over 37 countries, and the 2012 Middle East Respiratory Syndrome (MERS-CoV) covered 27 countries (World Health Organization, 2019; Cui et al., 2019). Unlike the previous coronaviruses, the COVID-19 pandemic has been particularly devastating, causing a global health and economic crises. It is challenging to ascertain the precise impact of the COVID-19 pandemic on the correlates of the economy. As Deaton and Schreyer (2020) poignantly stated, material well-being comes second when there is a threat to health. Gross domestic product (GDP) omits much that is central to people's well-being. They further argue that GDP measures include health expenditures but tell us nothing about health outcomes-a notable example of an essential component of well-being that is omitted and one that is of apparent salience during a pandemic. The expected impact would be different for demographic groups based on socioeconomic status.

However, recent trends of the pandemic's impact can be utilized to estimate the magnitude of present economic devastation and possibly the anticipated influence on measures 
of economic growth, effects on households, and demographical impacts. The adverse economic effects of the COVID-19 pandemic have already manifested in several sectors of the economy, particularly in tourism, agriculture, manufacturing, financial, small businesses, and trade. Pedro Brinca, Joao B. Duarte, and Miguel Faria-Castro (2020) found that the total private employment growth rate of hours worked fell about $2.5 \%$ (nonannualized); supply shocks they argued accounted for about two-thirds of this decline. Their study found that the growth rate of hours worked fell by 10 percentage points in the Leisure and Hospitality sector. Again, these are industries or sectors of the economy where Blacks and Hispanics are primarily employed. Goolsbee and Syverson (2020) concluded that government policies restricting business operations and personal mobility were less important than consumers' self-imposed limitations in contributing to the steep drop on economic activity during the early months of the COVID-19 pandemic. Voluntary behavioral changes occurred because of consumers' fears of catching the virus, they argued.

The impact of health-related issues on income and reverse causation between the two has been argued (Deaton, 2002). $\mathrm{He}$ states that mortality and morbidity rates are inversely related to many correlates of socioeconomic status, such as income, wealth, or social class. In the USA, racial (ethnic) differences persist in major chronic health issues (U.S Department of Health and Human Services, 2013). For example, regarding measures of population health, racial (ethnic) minorities, especially African Americans, perform poorly compared to Whites (Centers for Disease Control and Prevention, 2013). This health disparity, according to Fujishiro et al., is due partly to differential occupational exposure, a manifestation of socioeconomic position (SEP), that explains racial (ethnic) health disparities (Fujishiro \& Heaney, 2017). Potentially hazardous jobs are often found in the lower strata of SEP. Thus, occupations with a high percentage of African Americans and other ethnic minorities are more likely to report poor health (Chung-Bridges et al., 2008). The high control jobs such as management and professional occupations in which racial (ethnic) minorities are underrepresented are generally found in higher strata of SEP (Bureau of Labor Statistics, 2015). In general, White workers in high SEP jobs disproportionately experience health-protecting effects of job control.

During pandemics, socioeconomic status (education and income) has been shown to be associated with a higher level of compliance with preventive measures (Lau et al., 2003); (Liao et al., 2011). Pew Research 2020 also revealed that people with at least some college-level educations are likely to describe the coronavirus outbreak as a significant crisis. Commodari (2017) researched the role of sociodemographic factors such as age, gender, education, and status of employment on the perceived risk of disease outbreak.
The result showed that younger respondents believed they were at lower risk than the older adults, and a countervailing result showed that less-educated participants rather believed themselves to be at higher risk than most educated peers.

The COVID-19 pandemic and the associated governmental restrictions on individual's mobility and company closures have led to high social and economic costs in the USA and worldwide. Unemployment rates have risen across world economies. In the USA, according to the Bureau of Labor Statistics, about 44 million US workers filed for unemployment benefits claims just a few weeks after the pandemic outbreak. Pew Research showed that 33\% of American households reported a loss of job, pay cut, or reduction in work hours due to COVID-19 pandemic. About half of the respondents said the virus is a threat to their finances, and approximately $88 \%$ said the COVID-19 pandemic is a significant threat to the US economy (Pew Research Center, 2020). Demographically, the COVID-19 affected significant portions of low-income and younger populations in terms of its economic impact. About half or $49 \%$ of Hispanics younger population reported a job loss or pay reduction in their household compared to $36 \%$ of Blacks and $29 \%$ of White respondents. The older population is somewhat more concerned with health threats. Nearly half or $47 \%$ of people aged 50 years and above see the COVID-19 pandemic as a personal health threat than those below 50 years of age.

However, the economic impact on the labor force differs demographically. Of the unprecedented economic impact of the COVID-19 pandemic on job loss, Hispanics and Blacks are the most vulnerable. A Pew Research survey showed that as it relates to job loss or being laid off, about $29 \%$ of Hispanics, $22 \%$ of Blacks, and $17 \%$ of White ethnicities suffered as of March 2020. While the unemployment rates for Asian and White men increased sharply in the COVID-19 pandemic recession, they remain below the rates for Black and Hispanic men. By May 2020, among other men, Black ethnicity unemployment rose to $15.8 \%$, and Hispanic workers faced an unemployment rate of $15.5 \%$ higher than the rates for Asian $13.3 \%$ and White $9.7 \%$ men. Hispanic women had the highest unemployment rate at $19.5 \%$ compared with other women or men among the nation's major racial and ethnic groups. The unemployment rate for White women was $11.9 \%, 16.7 \%$ for Asian women, and $17.2 \%$ for Black women (Kochhar, 2020).

The unemployment rate among young adults ages 16 to $24(25.3 \%)$ exceeded the rate among other workers by a substantial margin, more than double the rate among workers 35 years and older. The primary reason is the concentration of young adults in higher-risk industries, such as food services that required the need for social distancing thus were directly impacted by government-mandated shutdowns. The rates are lower among workers with higher levels of education. Workers with a bachelor's degree or 
higher $7.2 \%$, in contrast to $18.5 \%$ of workers without a high school diploma, were unemployed in May 2020 estimates (Pew Research Center calculations). The US labor market had been impacted tremendously, with more than 36 million filings for unemployment insurance benefits (Bureau Of Labor Statistics, 2020).

The effects of the COVID-19 pandemic and overall economic decline for minority small businesses and predominantly Black- and Hispanic-owned businesses are noteworthy. Using Nationally representative data, Fairlie (2020) concludes that the COVID-19 pandemic hit African American business owners the hardest. The first estimates from April 2020 for Black business owners indicate a massive drop of $41 \%$ in business activity. Hispanic business owner activity fell by $32 \%$, and Asian business owner activity dropped by $26 \%$. The study also found that immigrant business owners experienced substantial losses in business activity of $36 \%$. Female business owners were also disproportionately affected by a drop of $25 \%$ in business activity. In contrast, White business owners only experienced a drop of $17 \%$ in business activity. Overall, business activity in the USA fell by $22 \%$. Government restrictions, forced closings, and modified re-openings of small businesses are striking across racial and ethnic groups.

In addition, the pandemic also revealed a disparity in mortality rates across demographics. Demographic and geographic trends in COVID-19 pandemic-associated deaths continue to occur disproportionately among older persons and certain racial and ethnic minorities, particularly among Black and Hispanic races (Centers for Disease Control and Prevention, 2020a, b) .

Since the pandemic has created isolation from normality, the usage of digital platforms to close this divide has never been more critical. However, access to technology has become a burden on the poor and rural dwellers. Pew Research survey found that 53\% of Americans said the Internet has been essential during the COVID-19 pandemic outbreak. However, Americans with lower incomes are particularly likely to have concerns about the digital divide and the digital "homework gap." Mills and Battisto (2020) found that counties with the highest concentration of COVID-19 cases are also the areas with the highest concentration of Black businesses and networks. Their study further concludes that there are stark Paycheck Protection Program (PPP) coverage gaps in these hardest-hit communities.

This study is significant for two reasons. First, it documents the loss of employment income on various households in the USA during the COVID-19 pandemic period from March 13, 2020, to November 9, 2020. Second, it examines the effect on the different ethnic groups based on demographic and socioeconomic status of these households. This study is particularly important to further our understanding of the impact of the COVID-19 pandemic on US households and document the impact on the different racial/ ethnic groups in the USA.

One advantage of using household survey data in economic and health studies is that it provides us with further insight into the distribution of poverty and inequality in society. In light of the above-highlighted background of the COVID-19 pandemic on US households, we posit that the loss of employment income will be positively correlated to household income, educational status, and employment. However, we have no a priori expectation of the correlation between location, race/ethnicity, and gender.

\section{Model}

The model measures the probability of a household experiencing loss of employment income over the COVID-19 pandemic period.

$Y i_{t}=\beta X i_{t}+\mu i_{t}$

where $Y_{t}$ is a binary variable that takes the value of 1 or 0 . If the ith household has experienced a loss of employment income since March 13, 2020, $\mathrm{Y}_{\mathrm{t}}$ is 1; otherwise, $\mathrm{Y}_{\mathrm{t}}$ is $0 . \mathrm{X}$ is a vector of independent variables, and $\beta$ is the vector of coefficients to be estimated, while $\mu$ is the error term. The independent variables consist of demographic variables, socioeconomic variables, access to technology variables, and location. Thus, we can write the loss of employment income equation as follows:

$\mathrm{Y}=1$ if the household has experienced a loss of employment income since March 13, 2020

or $\mathrm{Y}=0$ Otherwise.

The logistic equation to be estimated is generally expressed as the probability $\mathrm{P}$, of loss of employment income by a household due to the COVID-19 pandemic.

$$
\begin{gathered}
P(\text { Loss of employment income }=1 \mid \boldsymbol{x})=\boldsymbol{F}(\boldsymbol{x}, \boldsymbol{\beta}) \\
P(\text { No loss of employment income }=0 \mid \boldsymbol{x})=1-\boldsymbol{F}(\boldsymbol{x}, \boldsymbol{\beta})
\end{gathered}
$$

where $\mathbf{x}$ represents a vector of socioeconomic and demographic characteristics, $\boldsymbol{\beta}$ represents a vector of the estimated coefficients, and $\mathbf{F}$ is the cumulative distribution function.

For the loss of employment income equation, the survey question asks have you or anyone in your household experienced a loss of employment income since March 13, 2020 ? (1) Yes, (2) No.

The expected loss of employment income equation is based on the 2020 Household Pulse Survey question: Do you expect that you or anyone in your household will experience a loss of employment income in the next 4 weeks because of the coronavirus pandemic? (1)Yes, (2) No. 
The probability of expected loss of employment income is given by:

$P($ Expected loss of employment income $=1 \mid \boldsymbol{x})=\boldsymbol{F}(\boldsymbol{x}, \boldsymbol{\beta})$ $P($ No Expected loss of employment income $=0 \mid \boldsymbol{x})=1-\boldsymbol{F}(\boldsymbol{x}, \boldsymbol{\beta})$

\section{Data Source and Survey Information}

This study utilized pooled cross-sectional data from HPS. HPS is cross-sectional data collected weekly from April 23, 2020, is released biweekly, and is ongoing. For this study, we used Phase 2 data which spanned from August 19, 2020, to October 26, 2020. Additionally, we added the first-week survey of Phase 3 data to our study, which started from October 28, 2020, to November 9, 2020. HPS is designed to produce estimates at three different geographical levels. The first level, the lowest geographical area, is for the 15 largest metropolitan statistical areas (MSAs). The second level of geography is state-level estimates for each of the 50 states plus the District of Columbia, and the final level of geography is nationallevel estimates. Sample sizes were determined such that a three-percentage coefficient of variation $(\mathrm{CV})$ for an estimate of $40 \%$ of the population would be achieved for all sample areas with the exception of the 11 smallest states. In these smaller states, the sample size was reduced to produce a $3.5 \% \mathrm{CV}$. The overall sample sizes within the sampling areas were adjusted for an anticipated response rate of $9 \%$. Approximately 1,033,000 housing units were selected from the sampling frame for the first collection period of Phase 2. Approximately 109,000 respondents answered the online questionnaire.

The final HPS weights are designed to produce biweekly estimates for the total persons aged 18 and older living within housing units (HUs). These weights were created by adjusting the household-level sampling base weights by various factors to account for nonresponse, adults per household, and coverage. The sampling base weights for each incoming sample in each of the 66 sample areas are calculated as the total eligible HUs in the sampling frame divided by the number of eligible HUs selected for interviews each week. Therefore, the base weights for all sampled HUs sum to the total number of HUs for which contact information is known.

The final HPS person weights are created by applying the following adjustments to the sampling base weights:

(1) Nonresponse adjustment - the weights of all sample units that did not respond to the HPS are evenly allocated to the units that did respond within the same sam- ple collection period, sample area (MSA or balance of state), and state. After this step, the weights of all respondents sum to the total HUs with contact information in the sampling frame.

(2) Occupied HU ratio adjustment - this adjustment corrects for undercoverage in the sampling frame by inflating the $\mathrm{HU}$ weights after the nonresponse adjustment to match independent controls for the number of occupied HUs within each state. Each sampled respondent was assigned to the state where they reported their current address, which may be different from the selected state. For this adjustment, the independent controls are the 2018 American Community Survey (ACS) 1-year, state-level estimates available at www.census.gov2.

(3) Person adjustment- this adjustment converts the HU weights into person weights by multiplying them by the number of persons aged 18 and older that were reported to live within the household. The number of adults is based on subtracting the number of children under 18 in the household from the number of total persons in the household. This number was capped at 10 adults. If the number of total persons and number of children was not reported, then it is imputed.

Educational attainment estimates from the 2018 1-year ACS estimates (Table B115001)3 by age and sex, and the July 1, 2020, Hispanic origin/race by age and sex estimates from the Census Bureau's Population Estimates Program (PEP). PEP provided July 1, 2020, household population estimates by single year of age $(0-84,85+)$, sex, race (31 groups), and Hispanic origin for states from the Vintage 2019 estimates series4. The ACS 2018 estimates were adjusted to match the 2020 pop controls within states by sex and the five age categories in the ACS educational attainment estimates (US Census Bureau 2020).

\section{Definition Variables}

The variables for our logistic regression are loss of employment income which is a categorical variable of 1 or 0 . Household educational status is measured by college degree or no college degree. Does the household have insurance? Does the household have access to the Internet or computer? We have demographic variables of age, income, employment, health status, marital status, race, and location measured with region and environment, which represent the survey weeks. Race is a categorical variable where White $=1$, Black $=2$, Asian $=3$, and Other race $=4$. Both the income and age variables were recoded into categorical variables. 


\section{Blinder-Oaxaca Decomposition}

The Blinder-Oaxaca decomposition has been used to study labor market wage discrimination in gender and race. Nielsen (1998) concludes that discrimination accounted for $26 \%$ of the gender difference in formal sector employment in Zambia, while qualification only accounted for $4.5 \%$.

Fairlie (2005) extended the Blinder-Oaxaca decomposition into a nonlinear model. The basic Blinder-Oaxaca decomposition is used to measure the gap or difference between the different ethnic groups in both loss of employment income and expected loss of employment income. The average value of the dependent variable loss of employment income, $\mathrm{Y}$, is expressed such that:

$\stackrel{-W}{Y}^{-}-\stackrel{Y}{ }^{-}=\left[\left(\stackrel{-}{X}^{-}-{ }^{-B}\right) \hat{\beta}^{W}\right]+\left[{ }^{-B}\left(\hat{\beta}^{W}-\hat{\beta}^{B}\right)\right]$

$$
-j
$$

where $X$ is a row vector of average values of the independent variables and $\widehat{\beta}^{\mathrm{j}}$ is a vector of coefficient estimates for race $\mathrm{j}$. The decomposition of a nonlinear loss of employment income and expected loss of employment income equation, $Y=F(X \hat{\beta})$, may be expressed as: or $(44,716 / 558451)$ are Blacks, $5.07 \%$ or $(28,296 / 558451)$ and $5.05 \%$ or $(28,183 / 558451)$ are Asians and Other races, respectively. An analysis of the table on income and work loss shows that those earning less than $\$ 75,000$ accounted for $64.4 \%$ of the loss of employment income, while those households earning $\$ 75,000$ or more accounted for $46.81 \%$ of the loss of employment income over six surveys. A similar trend emerged with education and loss of employment income. Those households with a college degree or more accounted for $47.47 \%$ of the loss of employment income over the survey period, while those households without a college degree accounted for $52.53 \%$ of the loss of employment income during this period. A further look at the data shows that those households with graduate or professional degrees only accounted for $19.72 \%$ of the loss of employment income.

Among those surveyed between August 9 and November 19,2020 , the average loss of employment income for Whites is $36.69 \%$ compared to $47.16 \%, 38.82 \%$, and $49.54 \%$ for Blacks, Asians, and Other, respectively. Black households are 1.28 times more likely to experience loss of employment income than Whites between March 13 and November 9, 2020, due to the COVID-19 pandemic. For Asians, the gap

$\stackrel{-W}{Y}^{-B}-\stackrel{Y}{=}=\left[\left(\sum_{I=1}^{N^{w}} F\left(X_{i}^{w} \widehat{\beta}^{W}\right) / N^{W}-\left(\sum_{i=1}^{N^{B}} F\left(X_{I}^{B} \widehat{\beta}^{W}\right) / N^{B}\right]+\left[\left(\sum_{i=1}^{N^{W}} F\left(X_{i}^{w} \widehat{\beta}^{W}\right) / N^{B}-\left(\sum_{i=1}^{N^{B}} F\left(X_{i}^{B} \widehat{\beta}^{B}\right) / N^{B}\right]\right.\right.\right.\right.$

where $\mathrm{N}^{\mathrm{j}}$ is the sample size for race $\mathrm{j}$. The first term in brackets in both Eqs. 4 and 5 is the part of racial loss of employment income and expected loss of employment income differences that are due to group differences from the independent variables. The second term is the group differences from unobserved endowments or unexplained differences in loss of employment income and expected loss of employment income among the racial groups.

Jann (2008) developed the Oaxaca command in Stata to implement the Blinder-Oaxaca decomposition for linear regression models. He also showed how the process could be applied in logit or probit models. Sinning et al. (2008) developed both linear and nonlinear Stata commands to implement the Blinder-Oaxaca decomposition.

\section{Descriptive Statistics}

Table 1 represents the descriptive statistics. A look at Table 1 on race and loss of employment income shows that from March 15 to November 9, 2020, 38.29\% of the households surveyed experienced a loss of employment income due to the COVID-19 pandemic. The table also shows that 81.88 or $(457,256 / 558451)$ are Whites, $8.08 \%$ in loss of employment income is 1.063 times higher when compared to Whites. However, the figure is much higher for Other. Other is 1.35 times more likely to experience loss of employment income than Whites over the survey period. When we examine the loss of employment income for Hispanic households on data based on Hispanic or not Hispanic origin, the figure is $50.65 \%$ which is 1.38 times higher than for Whites.

A look at Table 1 on income categories shows the loss of employment income for White households that earn less than $\$ 25,000$ is $4.04 \%$; for Blacks, this is $10.41 \%$, and $4.15 \%$ and 9.80\% for Asians and Other, respectively. Perhaps, a better insight is to look at the loss of employment income for households that make less than an amount equal to $\$ 75,000$, which is the benchmark used by the US Congress for the CARES Act of 2020 for individuals and $\$ 199,910$ for households with joint income. The loss of employment income for White households that earn $\$ 75,000$ or less is $18.37 \%$ and $33.26 \%$ for income level $\$ 199,910$ or less. These statistics are highly significant when you compare them to the different ethnic groups or races. For Blacks who earn $\$ 75,000$ or less, the loss of employment income is $33.08 \%$ or $80 \%$ higher or 1.8 times the loss of employment income over the COVID-19 pandemic than Whites. This figure is also high for Other. It is $73 \%$ higher or 1.73 times higher than it is for White households. However, 
Table 1 Descriptive statistics on loss of employment income by US households

Household loss of employment Income by Race on Income Category August 19 to November 9, 2020

$\begin{array}{lllll}\text { Income category } & \text { White } & \text { Black } & \text { Asian } & \text { Other } \\ \text { Less than } \$ 25,000 & .0404 & .1041 & .0415 & .0980 \\ >\$ 25,000 \text { and } \leq 34,999 & .0349 & .0718 & .0352 & .0670 \\ >\$ 35,000 \text { and } \leq 49,999 & .0427 & .0707 & .0419 & .0660 \\ >\$ 50,000 \text { and } \leq 74,999 & .0657 & .0842 & .0643 & .0874 \\ >\$ 75,000 \text { and } \leq 99,999 & .0549 & .0514 & .0511 & .0640 \\ >\$ 100,000 \text { and } \leq 149,999 & .0645 & .0459 & .0663 & .0640 \\ >\$ 150,000 \text { and } \leq 199,999 & .0296 & .0197 & .0354 & .0256 \\ >\$ 200,000 & .0304 & .0121 & .0459 & .0206\end{array}$

Household loss of employment income by race on age category August 19 to November 9, 2020

$\begin{array}{lllll}\text { Age category } & \text { White } & \text { Black } & \text { Asian } & \text { Other } \\ \text { Age equal or less than } 22 & .0081 & .0097 & .0145 & .0193 \\ \text { Age }>22 \text { and } \leq 32 & .0528 & .0795 & .0722 & .0956 \\ \text { Age }>\text { 32 and } \leq 42 & .0891 & .1234 & .0999 & .1395 \\ \text { Age }>42 \text { and } \leq 2 & .0875 & .1232 & .1040 & .1162 \\ \text { Age }>52 \text { and } \leq 62 & .0861 & .0974 & .0708 & .0880 \\ \text { Age }>62 \text { and } \leq 72 & .0392 & .0357 & .0244 & .0327 \\ \text { Age }>72 \text { and } \leq 82 & .0048 & .0031 & .0025 & .0043\end{array}$

Household loss of employment income by race on education category August 19 to November 9, 2020

$\begin{array}{lllll}\text { Education category } & \text { White } & \text { Black } & \text { Asian } & \text { Other } \\ \text { Less than high school } & .0024 & .0040 & .0028 & .0076 \\ \text { Some high school } & .0060 & .0136 & .0076 & .0121 \\ \text { High school graduate } & .0670 & .0767 & .0256 & .0711 \\ \text { Some college } & .1237 & .1281 & .0603 & .1275 \\ \text { Associate degree } & .0618 & .0571 & .0339 & .0567 \\ \text { Bachelor's degree } & .1954 & .1221 & .2122 & .1255 \\ \text { Graduate or professional } & .1768 & .1269 & .2695 & .1041\end{array}$

Household loss of employment income by race on gender August 19 to November 9, 2020

$\begin{array}{lllll}\text { Gender } & \text { White } & \text { Black } & \text { Asian } & \text { Other } \\ \text { Male } & .1491 & .1486 & .1864 & .1988 \\ \text { Female } & .2178 & .3230 & .2013 & .2966\end{array}$

Household loss of employment income by race on the 4 regions from August 9 to November 19,2020

$\begin{array}{lllll}\text { Region } & \text { White } & \text { Black } & \text { Asian } & \text { Other } \\ \text { Northeast } & .0637 & .0664 & .0590 & .0576 \\ \text { South } & .1022 & .2712 & .0863 & .1276 \\ \text { Midwest } & .0769 & .0708 & .0398 & .0651 \\ \text { West } & .1242 & .0632 & .2031 & .2452\end{array}$

Household loss of employment income by race for weeks of August

19 to November 9, 2020

\begin{tabular}{lllll} 
Weeks & White & Black & Asian & Other \\
Week 13 & .0704 & .0978 & .0783 & .0936 \\
Week 14 & .0719 & .0850 & .0799 & .0991 \\
Week 15 & .0646 & .0830 & .0698 & .0887 \\
Week 16 & .0620 & .0788 & .0660 & .0840 \\
Week 17 & .0585 & .0712 & .0581 & .0781 \\
Week 18 & .0397 & .0458 & .0360 & .0519 \\
\hline
\end{tabular}

for Asian households, the loss of employment income is very similar to White households. For Asian households earning $\$ 75,000$ or less, the loss of employment income is $18.29 \%$ compared to $18.37 \%$ for Whites. The same trend is observed for Asian households earning \$199,999 or less. The loss of employment income is $33.57 \%$ compared to $33.26 \%$ for Whites.

Regarding age categories, the loss of employment income for Whites is 42 years, and 15\%, 21.26\%, 18.66\%, and $25.44 \%$ for Blacks, Asians, and Other, respectively. Compared with Whites, Black households have $41.73 \%$ higher loss of employment income. The gap for Asian households is $24.40 \%$ higher and $69.60 \%$ higher for Other. For ages 62 years or less, the White households' loss of employment income is $32.36 \%$, while that of Black households is $43.32 \%$. For Asians in this category, the loss of employment income is $36.14 \%$, and $45.86 \%$ for Other. Blacks have a $33.87 \%$ higher loss of employment income than Whites, and for Asians, the difference between them and Whites is only $11.68 \%$. The difference in loss of employment income is higher for Other when compared to White households.

On educational attainment and loss of employment income among the different races, Blacks with a high school diploma experienced loss of employment income of $7.67 \%$ compared to $6.70 \%$ for Whites, and $2.56 \%$ and $7.11 \%$ for Asians and Other, respectively. However, Blacks experienced the lowest loss of employment income for those with a Bachelors' degree at $12.21 \%, 19.54 \%$ for Whites, and $21.22 \%$ and $12.55 \%$ for Asians and Other, respectively. This result is contrary to the other observed trends in this survey. A similar trend is observed for those with graduate or professional degrees. The loss of employment income is $17.68 \%$ for Whites, $12.69 \%$ for Blacks, $26.95 \%$, and $10.41 \%$ for Asians and others. Clearly, Asians with graduate or professional degrees experience higher loss of employment income than Whites, Blacks, and Other.

When we examine the data on gender and loss of employment income, we see that $14.91 \%$ of White males experienced a loss of employment income compared to $21.78 \%$ of White females. This gap is even higher for Blacks. $14.86 \%$ of Black men experienced loss of employment income compared to $32.38 \%$ for Black women. For Asians, the figure is second to Whites. $18.64 \%$ of Asian men experienced a loss of employment income compared to $20.13 \%$ of women. For Other, men experienced $19.88 \%$ loss of employment income compared to $29.66 \%$ for women. Clearly, women, regardless of race/ethnicity, had a much higher burden on loss of employment income from the COVID-19 pandemic than men. Distressingly, Black women had the highest loss of employment income of $32.38 \%$ than any other women. Other women followed with a loss of employment income of $29.66 \%$, followed by White women with $21.78 \%$ and $20.13 \%$ for Asian women, respectively. On loss of employment income by race on marital status, we see that married 
Asians experienced the highest loss of employment income. Whites have the lowest rate of loss of employment income for never married, while Blacks have the highest rate of loss of employment income for married cohorts.

In terms of location and loss of employment income, Blacks in the South have the highest loss of employment income than any other ethnic group at $27.12 \%$. Similarly, Other races living in the West have the highest loss of employment income with $24.52 \%$ and followed by Asians with $20.31 \%$. In the Midwest, Whites have the highest loss of employment income with $7.69 \%$. In the Northeast region, the loss of employment income seems to be even, although Blacks with $6.64 \%$ are the highest, Whites have a $6.37 \%$ loss of employment income followed by Asians with $5.90 \%$, and Other with $5.76 \%$.

As mentioned elsewhere, we use the weeks as a measure of the environment. From week 13 to week 18 of this survey data, that is, August 9 through November 19, 2020, we see a consistent gradual decline in loss of employment income for all the races. This shows the effects of the CARES Act in acting as a buffer for the households in absorbing the impact of the COVID-19 pandemic and the easing of the lockdowns in various parts of the country on the households and individuals beginning to go back to work. This observation is consistent with the reduction in the unemployment figure for the US economy over the same period.

\section{Logistic Regression Results}

Table 2 is the result of the logistic regression on loss of employment income. The result shows that there is no statistically significant difference in loss of employment income for Blacks and Asians compared to Whites. However, Other race is more likely to experience loss of employment income compared to Whites, Blacks, and Asians, respectively. This result is highly significant. The result on age category shows that for all races, those between 42 and 82 are less likely to experience loss of employment income. Asian and White women are more likely to experience loss of employment income than men. This result is not significant for Black and Other women. Widowed and divorced households are less likely to experience loss of employment income compared to married households. This result is highly significant for the combined model for all races and White household model. This result is not significant for Other, Asian, and Black models. However, never-married households are less likely to experience loss of employment income when compared to married households. This result only holds for the combined model, Whites, and Blacks but not for Asians and Other. For combined races, households that earn between $\$ 50,000$ and $\$ 200,000$ are more likely to experience loss of employment income. However, this result is the opposite for
Whites. White households that earn $\$ 100,000$ and more are less likely to experience loss of employment income due to the COVID-19 pandemic.

Households with college degrees or advanced degrees are less likely to experience loss of employment income than those without college degrees. This result is highly significant for the combined model, White, Black, and Asian households, respectively, but not for Other. Households with less than excellent health status are more likely to experience loss of employment income. Households that are not current with their mortgage are more likely to experience loss of employment income for all races. Households without health insurance are more likely to experience loss of employment income compared to insured households. This result is significant for all ethnic groups.

On the sector of employment, those who work for private companies, non-profit, self-employed, or family businesses are more likely to experience a significant loss of employment income than those employed by the government sector. Also interesting is the result on households who have difficulty with their payments in the last 7 days on household expenses, including but not limited to food, rent or mortgage, car payments, medical expenses, student loans, and more. The coefficients increased from 1.1 to 2.2 for those who had little difficulty to those who had a tough time making payments. This result is highly significant both in coefficient and magnitude. Compared to those who telework, those did not have a higher loss of employment income. However, those who did not experience any change in telework were less likely to experience loss in employment income. This result is significant for a combined model, Whites, but not for Blacks, Asians, and Other, respectively.

Compared to week 13, only Black households are less likely to experience loss of employment income for week 14. This result is not significant for Asian and Other households.

When we examine the loss of employment income on a regional basis, households in the South, Midwest, and West are less likely to experience loss of employment income than households in the Northeast. On an ethnic basis, Whites in the South, Midwest, and West are less likely to experience loss of employment income than Blacks, Asians, and Other, respectively. These results are similar to the descriptive statistics.

Table 3 shows the logistic regression models on weekly surveys. From Table 3, we see that Blacks are less likely to experience loss of employment income in week 14 survey than Whites. Other races had a highly significant loss of employment income over these survey periods. For all age categories higher than 22 years, weeks 13 and 17 had a significant reduction in loss of employment income. Week 16 survey appears to be the worst in loss of employment income for all income categories. Even those with a college degree saw a significant increase in loss of employment income in 


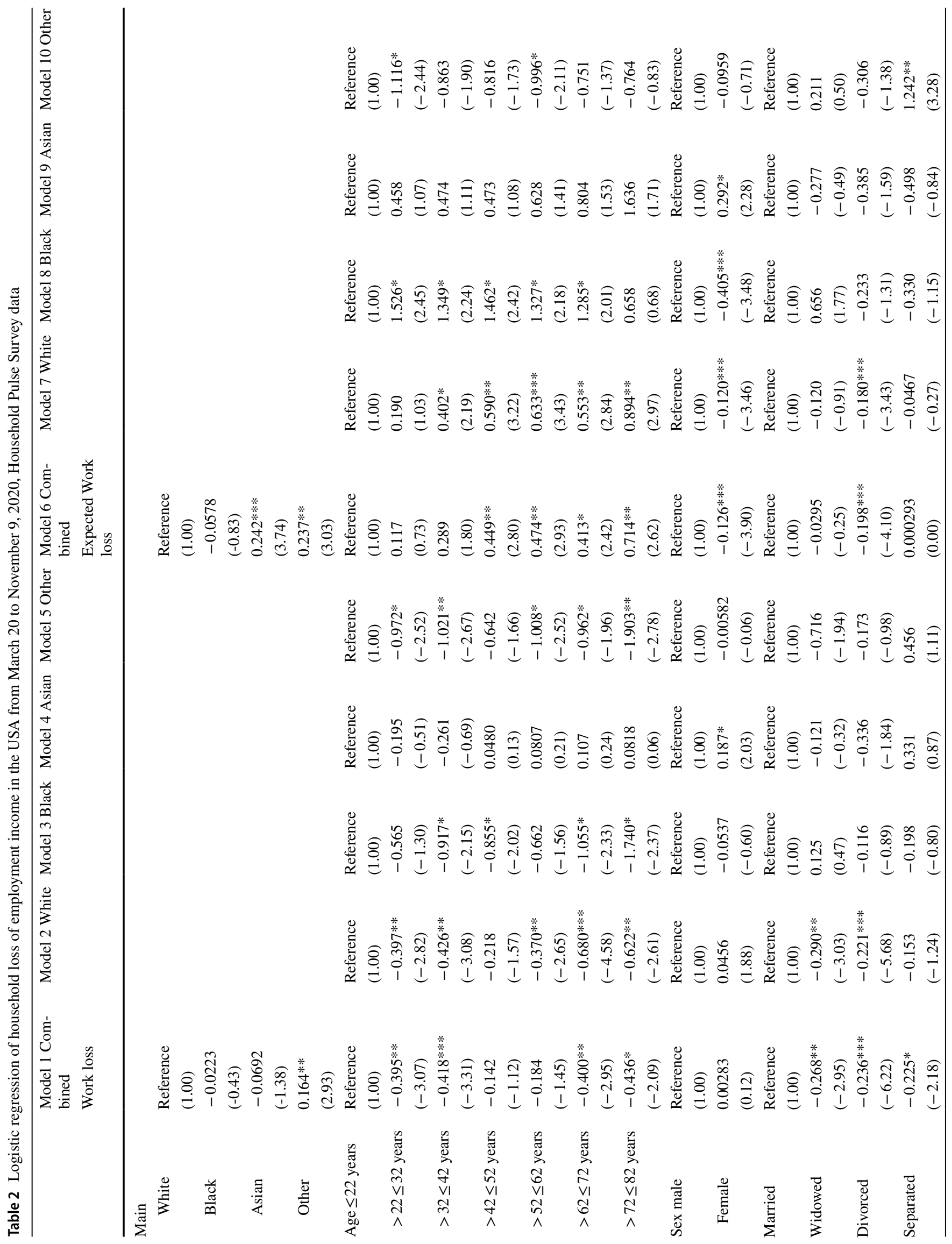




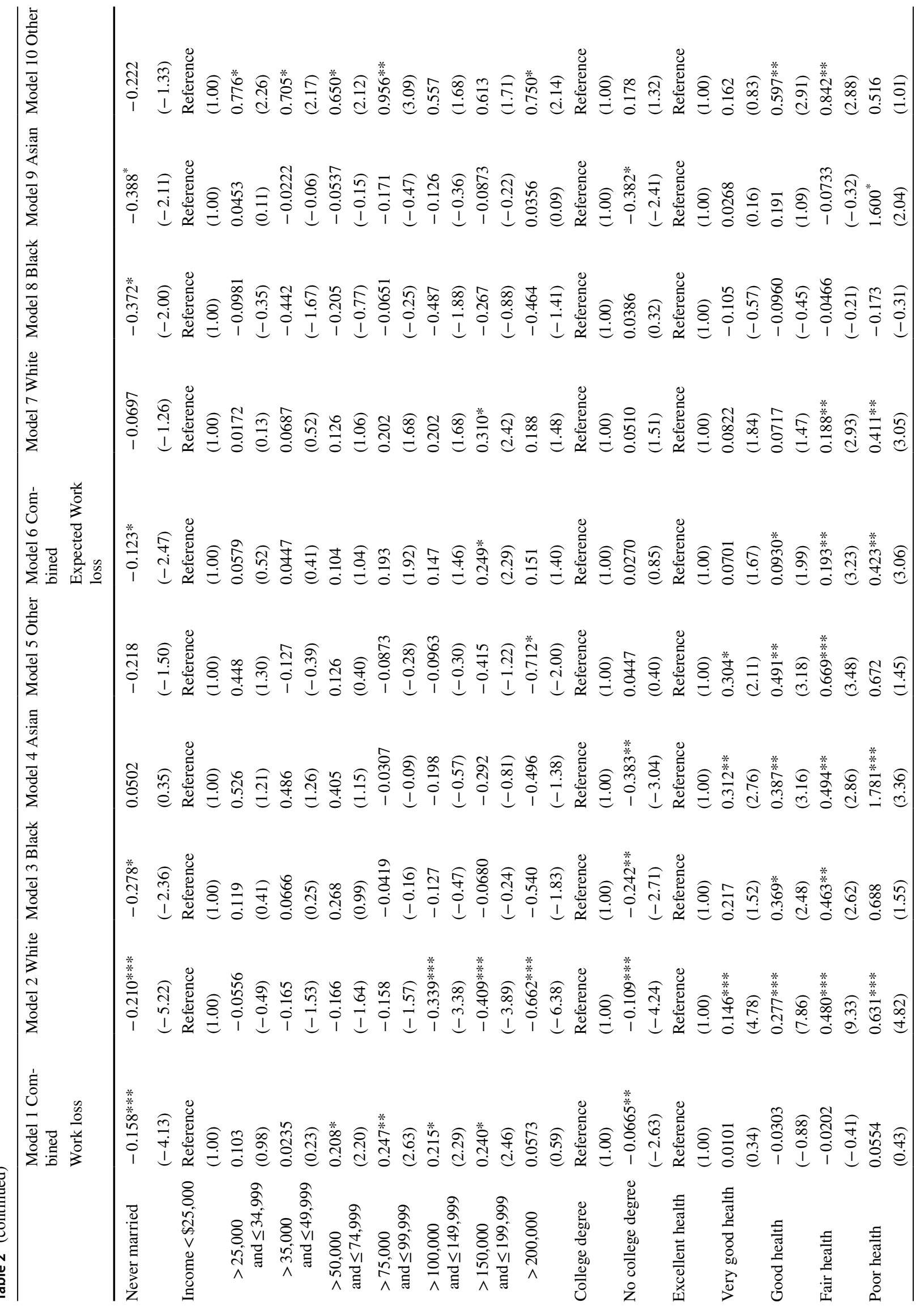




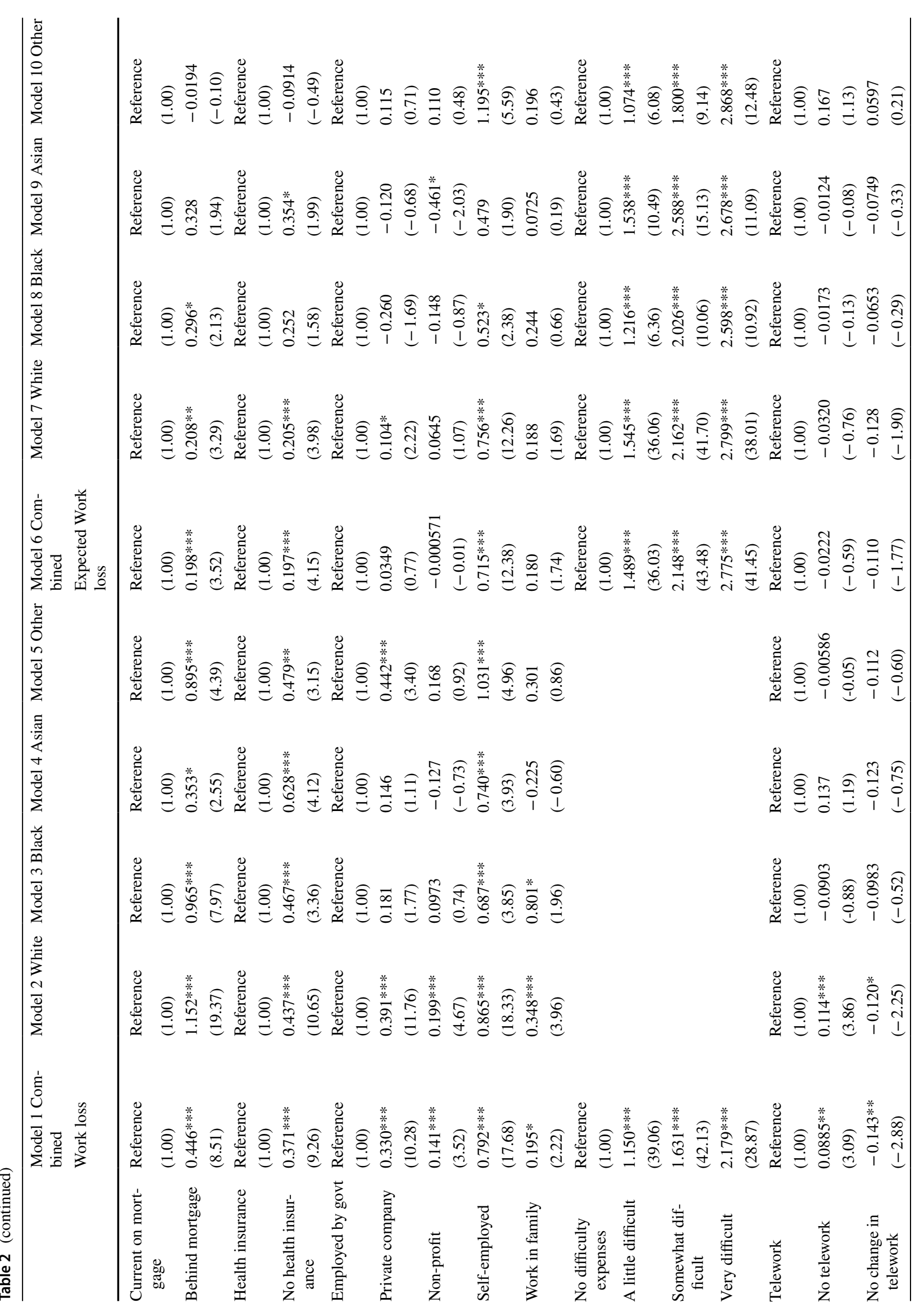




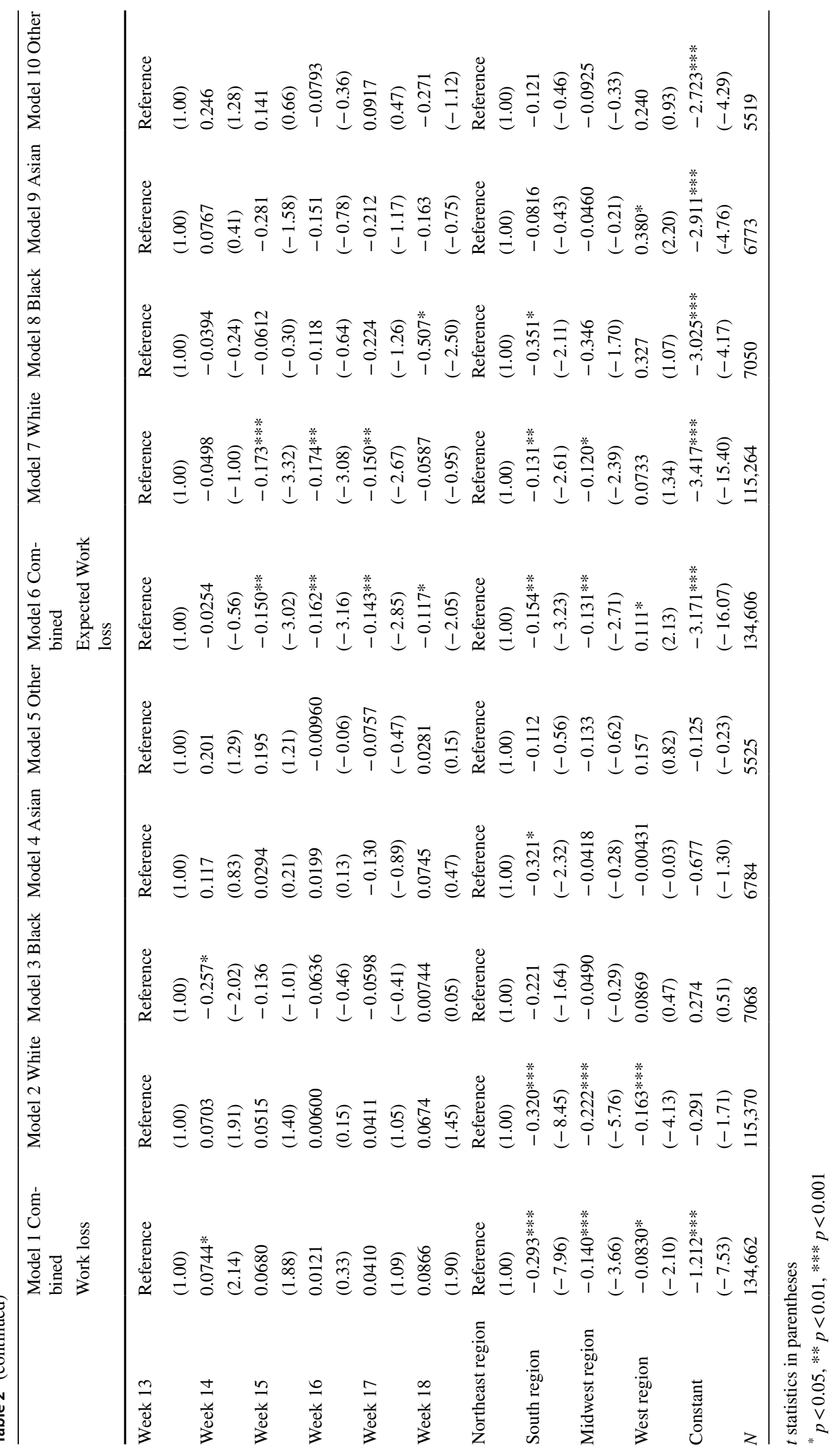


Table 3 Logistic Regression on US Households Loss of Employment Income August 19 to November 9, 2020

\begin{tabular}{|c|c|c|c|c|c|c|}
\hline Loss of employment income & Week 13 & Week 14 & Week 15 & Week 16 & Week 17 & Week 18 \\
\hline \multicolumn{7}{|l|}{ Loss of employment } \\
\hline White & $\begin{array}{l}\text { Reference } \\
(1.00)\end{array}$ & $\begin{array}{l}\text { Reference } \\
(1.00)\end{array}$ & $\begin{array}{l}\text { Reference } \\
(1.00)\end{array}$ & $\begin{array}{l}\text { Reference } \\
(1.00)\end{array}$ & $\begin{array}{l}\text { Reference } \\
(1.00)\end{array}$ & $\begin{array}{l}\text { Reference } \\
(1.00)\end{array}$ \\
\hline Black & $\begin{array}{l}0.0921 \\
(0.94)\end{array}$ & $\begin{array}{l}-0.238 * \\
(-2.40)\end{array}$ & $\begin{array}{l}-0.0143 \\
(-0.10)\end{array}$ & $\begin{array}{l}-0.0263 \\
(-0.23)\end{array}$ & $\begin{array}{l}0.0357 \\
(0.29)\end{array}$ & $\begin{array}{l}-0.0344 \\
(-0.23)\end{array}$ \\
\hline Asian & $\begin{array}{l}-0.0659 \\
(-0.67)\end{array}$ & $\begin{array}{l}0.00110 \\
(0.01)\end{array}$ & $\begin{array}{l}-0.0289 \\
(-0.26)\end{array}$ & $\begin{array}{l}-0.104 \\
(-0.86)\end{array}$ & $\begin{array}{l}-0.197 \\
(-1.66)\end{array}$ & $\begin{array}{l}-0.0688 \\
(-0.46)\end{array}$ \\
\hline Other & $\begin{array}{l}0.104 \\
(0.81)\end{array}$ & $\begin{array}{l}0.275^{*} \\
(2.36)\end{array}$ & $\begin{array}{l}0.320^{*} \\
(2.27)\end{array}$ & $\begin{array}{l}0.178 \\
(1.32)\end{array}$ & $\begin{array}{l}0.0206 \\
(0.17)\end{array}$ & $\begin{array}{l}0.0661 \\
(0.42)\end{array}$ \\
\hline Age $\leq 22$ years & $\begin{array}{l}\text { Reference } \\
(1.00)\end{array}$ & $\begin{array}{l}\text { Reference } \\
(1.00)\end{array}$ & $\begin{array}{l}\text { Reference } \\
(1.00)\end{array}$ & $\begin{array}{l}\text { Reference } \\
(1.00)\end{array}$ & $\begin{array}{l}\text { Reference } \\
(1.00)\end{array}$ & $\begin{array}{l}\text { Reference } \\
(1.00)\end{array}$ \\
\hline$>22 \leq 32$ years & $\begin{array}{l}-0.677^{* *} \\
(-2.68)\end{array}$ & $\begin{array}{l}-0.219 \\
(-0.74)\end{array}$ & $\begin{array}{l}-0.578^{+} \\
(-1.93)\end{array}$ & $\begin{array}{l}-0.227 \\
(-0.75)\end{array}$ & $\begin{array}{l}-0.755^{* *} \\
(-2.64)\end{array}$ & $\begin{array}{l}0.149 \\
(0.34)\end{array}$ \\
\hline$>32 \leq 42$ years & $\begin{array}{l}-0.790^{* *} \\
(-3.15)\end{array}$ & $\begin{array}{l}-0.252 \\
(-0.87)\end{array}$ & $\begin{array}{l}-0.579^{+} \\
(-1.95)\end{array}$ & $\begin{array}{l}-0.311 \\
(-1.03)\end{array}$ & $\begin{array}{l}-0.779 * * \\
(-2.74)\end{array}$ & $\begin{array}{l}0.274 \\
(0.67)\end{array}$ \\
\hline$>42 \leq 52$ years & $\begin{array}{l}-0.533^{*} \\
(-2.13)\end{array}$ & $\begin{array}{l}0.104 \\
(0.36)\end{array}$ & $\begin{array}{l}-0.328 \\
(-1.10)\end{array}$ & $\begin{array}{l}0.0626 \\
(0.21)\end{array}$ & $\begin{array}{l}-0.476^{+} \\
(-1.68)\end{array}$ & $\begin{array}{l}0.398 \\
(0.97)\end{array}$ \\
\hline$>52 \leq 62$ years & $\begin{array}{l}-0.494^{+} \\
(-1.96)\end{array}$ & $\begin{array}{l}0.0161 \\
(0.06)\end{array}$ & $\begin{array}{l}-0.315 \\
(-1.05)\end{array}$ & $\begin{array}{l}-0.0314 \\
(-0.10)\end{array}$ & $\begin{array}{l}-0.558^{+} \\
(-1.95)\end{array}$ & $\begin{array}{l}0.349 \\
(0.84)\end{array}$ \\
\hline$>62 \leq 72$ years & $\begin{array}{l}-0.667 * \\
(-2.40)\end{array}$ & $\begin{array}{l}-0.118 \\
(-0.38)\end{array}$ & $\begin{array}{l}-0.449 \\
(-1.42)\end{array}$ & $\begin{array}{l}-0.285 \\
(-0.90)\end{array}$ & $\begin{array}{l}-0.819 * * \\
(-2.67)\end{array}$ & $\begin{array}{l}0.00102 \\
(0.00)\end{array}$ \\
\hline$>72 \leq 82$ years & $\begin{array}{l}-1.474 * * * \\
(-3.60)\end{array}$ & $\begin{array}{l}-1.063 * \\
(-2.31)\end{array}$ & $\begin{array}{l}-0.153 \\
(-0.37)\end{array}$ & $\begin{array}{l}0.181 \\
(0.40)\end{array}$ & $\begin{array}{l}-0.591 \\
(-1.08)\end{array}$ & $\begin{array}{l}0.530 \\
(0.80)\end{array}$ \\
\hline Male & $\begin{array}{l}\text { Reference } \\
(1.00)\end{array}$ & $\begin{array}{l}\text { Reference } \\
(1.00)\end{array}$ & $\begin{array}{l}\text { Reference } \\
(1.00)\end{array}$ & $\begin{array}{l}\text { Reference } \\
(1.00)\end{array}$ & $\begin{array}{l}\text { Reference } \\
(1.00)\end{array}$ & $\begin{array}{l}\text { Reference } \\
(1.00)\end{array}$ \\
\hline Female & $\begin{array}{l}-0.0308 \\
(-0.64)\end{array}$ & $\begin{array}{l}-0.0341 \\
(-0.68)\end{array}$ & $\begin{array}{l}0.0302 \\
(0.55)\end{array}$ & $\begin{array}{l}0.0377 \\
(0.69)\end{array}$ & $\begin{array}{l}-0.0656 \\
(-1.15)\end{array}$ & $\begin{array}{l}0.0677 \\
(0.89)\end{array}$ \\
\hline Married & $\begin{array}{l}\text { Reference } \\
(1.00)\end{array}$ & $\begin{array}{l}\text { Reference } \\
(1.00)\end{array}$ & $\begin{array}{l}\text { Reference } \\
(1.00)\end{array}$ & $\begin{array}{l}\text { Reference } \\
(1.00)\end{array}$ & $\begin{array}{l}\text { Reference } \\
(1.00)\end{array}$ & $\begin{array}{l}\text { Reference } \\
(1.00)\end{array}$ \\
\hline Widowed & $\begin{array}{l}-0.405^{*} \\
(-2.23)\end{array}$ & $\begin{array}{l}0.0583 \\
(0.28)\end{array}$ & $\begin{array}{l}-0.465^{*} \\
(-2.15)\end{array}$ & $\begin{array}{l}-0.482 * * \\
(-2.86)\end{array}$ & $\begin{array}{l}-0.368^{+} \\
(-1.68)\end{array}$ & $\begin{array}{l}-0.0417 \\
(-0.15)\end{array}$ \\
\hline Divorced & $\begin{array}{l}-0.231 * * \\
(-2.73)\end{array}$ & $\begin{array}{l}-0.236^{* *} \\
(-2.87)\end{array}$ & $\begin{array}{l}-0.244 * * \\
(-2.91)\end{array}$ & $\begin{array}{l}-0.278 * * \\
(-3.20)\end{array}$ & $\begin{array}{l}-0.410 * * * \\
(-4.43)\end{array}$ & $\begin{array}{l}-0.0437 \\
(-0.39)\end{array}$ \\
\hline Separated & $\begin{array}{l}0.0721 \\
(0.28)\end{array}$ & $\begin{array}{l}-0.155 \\
(-0.79)\end{array}$ & $\begin{array}{l}-0.405 \\
(-1.74)\end{array}$ & $\begin{array}{l}-0.521 * \\
(-2.33)\end{array}$ & $\begin{array}{l}-0.680 * * \\
(-2.93)\end{array}$ & $\begin{array}{l}0.315 \\
(1.05)\end{array}$ \\
\hline Never married & $\begin{array}{l}-0.184 * \\
(-2.49)\end{array}$ & $\begin{array}{l}-0.206^{* *} \\
(-2.59)\end{array}$ & $\begin{array}{l}-0.149 \\
(-1.64)\end{array}$ & $\begin{array}{l}-0.128 \\
(-1.41)\end{array}$ & $\begin{array}{l}-0.304 * * * \\
(-3.40)\end{array}$ & $\begin{array}{l}0.0122 \\
(0.10)\end{array}$ \\
\hline Income $<\$ 25,000$ & $\begin{array}{l}\text { Reference } \\
(1.00)\end{array}$ & $\begin{array}{l}\text { Reference } \\
(1.00)\end{array}$ & $\begin{array}{l}\text { Reference } \\
(1.00)\end{array}$ & $\begin{array}{l}\text { Reference } \\
(1.00)\end{array}$ & $\begin{array}{l}\text { Reference } \\
(1.00)\end{array}$ & $\begin{array}{l}\text { Reference } \\
(1.00)\end{array}$ \\
\hline$>25,000$ and $<34,999$ & $\begin{array}{l}0.0949 \\
(0.46)\end{array}$ & $\begin{array}{l}-0.182 \\
(-0.86)\end{array}$ & $\begin{array}{l}-0.141 \\
(-0.60)\end{array}$ & $\begin{array}{l}0.568 * \\
(2.19)\end{array}$ & $\begin{array}{l}-0.0201 \\
(-0.08)\end{array}$ & $\begin{array}{l}0.368 \\
(1.23)\end{array}$ \\
\hline$>35,000$ and $<49,999$ & $\begin{array}{l}0.170 \\
(0.94)\end{array}$ & $\begin{array}{l}-0.0836 \\
(-0.42)\end{array}$ & $\begin{array}{l}-0.0852 \\
(-0.39)\end{array}$ & $\begin{array}{l}0.411 \\
(1.66)\end{array}$ & $\begin{array}{l}-0.0131 \\
(-0.06)\end{array}$ & $\begin{array}{l}-0.194 \\
(-0.64)\end{array}$ \\
\hline$>50,000$ and $<74,999$ & $\begin{array}{l}0.257 \\
(1.47)\end{array}$ & $\begin{array}{l}0.0200 \\
(0.11)\end{array}$ & $\begin{array}{l}0.0733 \\
(0.35)\end{array}$ & $\begin{array}{l}0.485^{*} \\
(2.02)\end{array}$ & $\begin{array}{l}0.298 \\
(1.45)\end{array}$ & $\begin{array}{l}0.178 \\
(0.64)\end{array}$ \\
\hline$>75,000$ and $<99,999$ & $\begin{array}{l}0.350 * \\
(1.99)\end{array}$ & $\begin{array}{l}0.0761 \\
(0.41)\end{array}$ & $\begin{array}{l}0.0939 \\
(0.44)\end{array}$ & $\begin{array}{l}0.435^{+} \\
(1.82)\end{array}$ & $\begin{array}{l}0.213 \\
(1.02)\end{array}$ & $\begin{array}{l}0.384 \\
(1.46)\end{array}$ \\
\hline$>100,000$ and $<149,999$ & $\begin{array}{l}0.213 \\
(1.22)\end{array}$ & $\begin{array}{l}0.103 \\
(0.55)\end{array}$ & $\begin{array}{l}0.0980 \\
(0.46)\end{array}$ & $\begin{array}{l}0.457^{+} \\
(1.90)\end{array}$ & $\begin{array}{l}0.247 \\
(1.20)\end{array}$ & $\begin{array}{l}0.227 \\
(0.87)\end{array}$ \\
\hline
\end{tabular}


Table 3 (continued)

\begin{tabular}{|c|c|c|c|c|c|c|}
\hline Loss of employment income & Week 13 & Week 14 & Week 15 & Week 16 & Week 17 & Week 18 \\
\hline \multirow[t]{2}{*}{$>150,000$ and $<199,999$} & 0.253 & 0.134 & 0.135 & 0.388 & 0.257 & 0.317 \\
\hline & $(1.40)$ & $(0.66)$ & $(0.62)$ & $(1.52)$ & $(1.20)$ & $(1.17)$ \\
\hline \multirow[t]{2}{*}{$\geq 200,000$} & 0.116 & -0.110 & -0.173 & 0.369 & 0.0585 & 0.137 \\
\hline & $(0.64)$ & $(-0.55)$ & $(-0.79)$ & $(1.48)$ & $(0.27)$ & $(0.50)$ \\
\hline \multirow{4}{*}{$\begin{array}{l}\text { Education } \\
\qquad \text { No college degree } \\
\text { College degree }\end{array}$} & Reference & Reference & Reference & Reference & Reference & Reference \\
\hline & $(1.00)$ & $(1.00)$ & $(1.00)$ & $(1.00)$ & $(1.00)$ & $(1.00)$ \\
\hline & $-0.0973^{+}$ & $-0.140 * *$ & $-0.136^{*}$ & $0.130^{*}$ & -0.0895 & -0.0488 \\
\hline & $(-1.90)$ & $(-2.60)$ & $(-2.31)$ & $(2.24)$ & $(-1.52)$ & $(-0.59)$ \\
\hline \multirow[t]{2}{*}{ Excellent health } & Reference & Reference & Reference & Reference & Reference & Reference \\
\hline & $(1.00)$ & $(1.00)$ & $(1.00)$ & $(1.00)$ & $(1.00)$ & $(1.00)$ \\
\hline \multirow[t]{2}{*}{ Very good health } & -0.0569 & -0.0674 & 0.0366 & 0.0844 & -0.0243 & 0.0839 \\
\hline & $(-0.91)$ & $(-1.06)$ & $(0.55)$ & $(1.22)$ & $(-0.35)$ & $(0.90)$ \\
\hline \multirow[t]{2}{*}{ Good health } & -0.0954 & -0.101 & 0.0805 & -0.0827 & -0.0648 & 0.0652 \\
\hline & $(-1.33)$ & $(-1.28)$ & $(1.01)$ & $(-1.02)$ & $(-0.78)$ & $(0.64)$ \\
\hline \multirow[t]{2}{*}{ Fair health } & 0.0285 & 0.0521 & 0.0178 & -0.0165 & -0.0555 & -0.148 \\
\hline & $(0.27)$ & $(0.46)$ & $(0.15)$ & $(-0.15)$ & $(-0.49)$ & $(-1.05)$ \\
\hline \multirow[t]{2}{*}{ Poor health } & 0.0910 & $-0.724 * *$ & -0.209 & 0.341 & 0.606 & 0.186 \\
\hline & $(0.35)$ & $(-2.64)$ & $(-0.87)$ & $(1.64)$ & $(1.65)$ & $(0.45)$ \\
\hline \multirow[t]{2}{*}{ Current on mortgage } & Reference & Reference & Reference & Reference & Reference & Reference \\
\hline & $(1.00)$ & $(1.00)$ & $(1.00)$ & $(1.00)$ & $(1.00)$ & $(1.00)$ \\
\hline \multirow[t]{2}{*}{ Behind on mortgage } & $0.583 * * *$ & $0.398 * * *$ & $0.398 * * *$ & $0.441 * * *$ & $0.238^{+}$ & $0.602 * * *$ \\
\hline & $(5.90)$ & (3.94) & $(3.46)$ & $(3.72)$ & $(1.71)$ & $(3.88)$ \\
\hline \multirow[t]{2}{*}{ Health insurance } & Reference & Reference & Reference & Reference & Reference & Reference \\
\hline & $(1.00)$ & $(1.00)$ & $(1.00)$ & $(1.00)$ & $(1.00)$ & $(1.00)$ \\
\hline \multirow[t]{2}{*}{ No health insurance } & $0.314 * * *$ & $0.443 * * *$ & $0.412 * * *$ & $0.319 * * *$ & $0.545^{* * *}$ & $0.232^{+}$ \\
\hline & $(3.84)$ & $(5.29)$ & $(4.87)$ & $(3.75)$ & $(5.72)$ & $(1.85)$ \\
\hline \multirow[t]{2}{*}{ Employed by government } & Reference & Reference & Reference & Reference & Reference & Reference \\
\hline & $(1.00)$ & $(1.00)$ & $(1.00)$ & $(1.00)$ & $(1.00)$ & $(1.00)$ \\
\hline \multirow[t]{2}{*}{ Private company } & $0.401 * * *$ & $0.307 * * *$ & $0.261 * *$ & $0.372 * * *$ & $0.218 * *$ & $0.407 * * *$ \\
\hline & $(5.91)$ & $(4.60)$ & $(3.14)$ & $(5.43)$ & $(2.65)$ & $(4.52)$ \\
\hline \multirow[t]{2}{*}{ Non-profit } & $0.256^{* *}$ & -0.00484 & 0.0652 & 0.129 & 0.146 & $0.217^{+}$ \\
\hline & $(3.01)$ & $(-0.06)$ & $(0.66)$ & $(1.34)$ & $(1.51)$ & $(1.85)$ \\
\hline \multirow[t]{2}{*}{ Self-employed } & $0.952 * * *$ & $0.703 * * *$ & $0.796 * * *$ & $0.734 * * *$ & $0.709 * * *$ & $0.862 * * *$ \\
\hline & $(9.95)$ & $(7.09)$ & $(7.37)$ & $(7.35)$ & $(6.36)$ & $(6.59)$ \\
\hline \multirow[t]{2}{*}{ Work in family } & 0.234 & 0.160 & 0.0228 & 0.196 & 0.244 & 0.285 \\
\hline & $(1.19)$ & $(0.76)$ & $(0.13)$ & $(0.87)$ & $(1.17)$ & $(1.27)$ \\
\hline \multirow[t]{2}{*}{ No difficulty expenses } & Reference & Reference & Reference & Reference & Reference & Reference \\
\hline & $(1.00)$ & $(1.00)$ & $(1.00)$ & $(1.00)$ & $(1.00)$ & $(1.00)$ \\
\hline \multirow[t]{2}{*}{ A little difficult } & $1.179 * * *$ & $1.163 * * *$ & $1.055^{* * *}$ & $1.116 * * *$ & $1.214 * * *$ & $1.203 * * *$ \\
\hline & $(20.10)$ & (18.99) & $(15.28)$ & $(16.71)$ & $(17.20)$ & $(12.80)$ \\
\hline \multirow[t]{2}{*}{ Somewhat difficult } & $1.604 * * *$ & $1.641 * * *$ & $1.610 * * *$ & $1.658 * * *$ & $1.582 * * *$ & $1.770 * * *$ \\
\hline & (19.19) & (20.30) & $(18.51)$ & $(17.25)$ & $(16.80)$ & $(15.51)$ \\
\hline \multirow[t]{2}{*}{ Very difficult } & $2.110 * * *$ & $2.316^{* * *}$ & $2.031 * * *$ & $2.334 * * *$ & $2.352 * * *$ & $2.090 * * *$ \\
\hline & $(17.28)$ & $(18.78)$ & $(14.67)$ & $(15.97)$ & $(13.58)$ & $(8.65)$ \\
\hline Telework & Reference & Reference & Reference & Reference & Reference & Reference \\
\hline & $(1.00)$ & $(1.00)$ & $(1.00)$ & $(1.00)$ & $(1.00)$ & $(1.00)$ \\
\hline No telework & 0.0198 & 0.0750 & 0.0470 & 0.110 & $0.173 *$ & 0.146 \\
\hline & $(0.34)$ & $(1.21)$ & $(0.72)$ & $(1.65)$ & $(2.56)$ & $(1.65)$ \\
\hline
\end{tabular}


Table 3 (continued)

\begin{tabular}{|c|c|c|c|c|c|c|}
\hline Loss of employment income & Week 13 & Week 14 & Week 15 & Week 16 & Week 17 & Week 18 \\
\hline \multirow[t]{2}{*}{ No change in telework } & -0.111 & $-0.196^{+}$ & $-0.277^{*}$ & 0.1000 & $-0.312 *$ & -0.0838 \\
\hline & $(-1.21)$ & $(-1.81)$ & $(-2.57)$ & $(0.94)$ & $(-2.33)$ & $(-0.58)$ \\
\hline \multirow[t]{2}{*}{ Northeast region } & Reference & Reference & Reference & Reference & Reference & Reference \\
\hline & $(1.00)$ & $(1.00)$ & $(1.00)$ & $(1.00)$ & $(1.00)$ & $(1.00)$ \\
\hline \multirow[t]{2}{*}{ South region } & $-0.356^{* * *}$ & $-0.314 * * *$ & $-0.316^{* * *}$ & $-0.241 * *$ & $-0.373 * * *$ & -0.195 \\
\hline & $(-4.80)$ & $(-4.07)$ & $(-3.93)$ & $(-3.03)$ & $(-4.38)$ & $(-1.52)$ \\
\hline \multirow[t]{2}{*}{ Midwest region } & $-0.297 * * *$ & $-0.143^{+}$ & -0.121 & -0.137 & $-0.152^{+}$ & -0.0387 \\
\hline & $(-3.84)$ & $(-1.77)$ & $(-1.43)$ & $(-1.65)$ & $(-1.76)$ & $(-0.29)$ \\
\hline \multirow[t]{2}{*}{ West region } & $-0.155^{*}$ & -0.110 & -0.0397 & 0.0527 & -0.128 & -0.124 \\
\hline & $(-2.04)$ & $(-1.38)$ & $(-0.46)$ & $(0.60)$ & $(-1.53)$ & $(-0.90)$ \\
\hline \multirow[t]{2}{*}{ Constant } & $-0.829 * *$ & $-1.036 * *$ & $-0.776^{+}$ & $-1.811 * * *$ & $-0.633^{+}$ & $-2.027 * * *$ \\
\hline & $(-2.59)$ & $(-2.96)$ & $(-1.94)$ & $(-4.74)$ & $(-1.80)$ & $(-4.16)$ \\
\hline$N$ & 25,730 & 26,347 & 23,985 & 23,220 & 21,600 & 13,780 \\
\hline
\end{tabular}

$t$ statistics in parentheses

$p<0.10^{+}, * p<0.05, * * p<0.01, * * * p<0.001$

the week 16 survey. As noted in the results in Table 2, elsewhere for sector of employment, those who work for private companies, non-profit, self-employed, or family businesses were more likely to experience a significant loss of employment income than those employed by the government sector.

The results on households who have difficulty with their payments in the last 7 days on household expenses include, but not limited to, food, rent or mortgage, car payments, medical expenses, student loans, and more. The coefficients increased from 1.1 to 2.3 , which are slightly higher than our result from Table 2, for those who had little difficulty to those who had a very difficult time making payments. This result is highly significant both in coefficient and magnitude. A similar result emerged with those who are able to telework during the COVID-19 pandemic. Those who are able to telework are less likely to experience loss of employment income compared to those who were not able to telework. However, those who did not experience any change in telework were less likely to experience loss in employment income. These results are consistent with the Pew Research findings and also the NPR, the Robert Woodson Foundation, and Harvard University study on the financial distress of COVID-19 pandemic on the different ethnic groups.

\section{Blinder-Oaxaca Decomposition Results}

Tables 4 and 5 show Blinder-Oaxaca decomposition analysis. For all the races, the mean loss of employment income is 0.489 compared to 0.578 , for Blacks, resulting in a difference of -0.0885 as shown in Table 4 . The negative 0.0885 represents the mean difference in loss of employment income experienced by Blacks from the population mean loss of employment income over the survey period. Stated differently, Blacks experienced a loss of employment income that is almost $9 \%$ higher than any other race/ethnic group. Differences in endowments explain $69.15 \%$ of this difference in loss of employment income, while $30.85 \%$ is unexplained by differences in endowments. For Other race, the mean difference from the population mean of loss of employment income is -0.0640 . Other race mean loss of employment income is $6.4 \%$ higher than the mean population loss of employment income. $82.19 \%$ of this difference is explained by differences in endowments, while $17.81 \%$ is unexplained by differences in endowments. The unexplained differences in loss of employment income due to endowments are the differences attributable to characteristics or discrimination. The mean loss of employment income for Whites is 0.487 compared to the rest of other races of 0.542 , resulting in a mean difference of 0.0550 . White mean loss of employment income is lower by 0.0550 or $5.5 \%$ from the population mean. $66.9 \%$ of this difference is explained by endowments, while $33.1 \%$ is unexplained. For Asians, the mean loss of employment income is lower than the population mean by 0.0707 . $91.65 \%$ of this difference in loss of employment income is explained by endowments, while $8.35 \%$ is unexplained.

On the detailed Blinder-Oaxaca decomposition on Table 5, the mean loss of employment income for Blacks is higher than the population mean loss of employment income by $0.0945 .73 .33 \%$ is explained by differences in endowments, while $26.67 \%$ is unexplained by differences in endowments. Income explained $43.87 \%$ of the differences explained by endowments. Health insurance explained $24.82 \%$ of the differences explained by endowments, while health explained $17.89 \%$ of the differences explained by 
Table 4 Blinder-Oaxaca-weighted decomposition on loss of employment income with Household Pulse Survey

\begin{tabular}{|c|c|c|c|c|c|c|c|c|}
\hline & Black (1) & & White (2) & & Asian (3) & & Other (4) & \\
\hline & $\begin{array}{l}\text { Loss of employ- } \\
\text { ment }\end{array}$ & & $\begin{array}{l}\text { Loss of employ- } \\
\text { ment }\end{array}$ & & $\begin{array}{l}\text { Loss of employ- } \\
\text { ment }\end{array}$ & & $\begin{array}{l}\text { Loss of employ- } \\
\text { ment }\end{array}$ & \\
\hline \multicolumn{9}{|l|}{ Differential } \\
\hline $\begin{array}{l}\text { Base group } \\
\text { mean }\end{array}$ & $\begin{array}{l}0.489 * * * \\
(141.50)\end{array}$ & & $\begin{array}{l}0.542 * * * \\
(81.49)\end{array}$ & & $\begin{array}{l}0.506 * * * \\
(149.35)\end{array}$ & & $\begin{array}{l}0.497 * * * \\
(148.52)\end{array}$ & \\
\hline $\begin{array}{l}\text { Analyzed group } \\
\text { mean }\end{array}$ & $\begin{array}{l}0.578 * * * \\
(60.99)\end{array}$ & & $\begin{array}{l}0.487 * * * \\
(130.84)\end{array}$ & & $\begin{array}{l}0.435 * * * \\
(38.37)\end{array}$ & & $\begin{array}{l}0.561 * * * \\
(41.82)\end{array}$ & \\
\hline Difference & $\begin{array}{l}-0.0885 * * * \\
(-8.77)\end{array}$ & & $\begin{array}{l}0.0550 * * * \\
(7.21)\end{array}$ & & $\begin{array}{l}0.0707 * * * \\
(5.97)\end{array}$ & & $\begin{array}{l}-0.0640 * * * \\
(-4.62)\end{array}$ & \\
\hline \multicolumn{9}{|l|}{ Decomposition } \\
\hline Explained & $\begin{array}{l}-0.0612 * * * \\
(-14.70)\end{array}$ & $69.15 \%$ & $\begin{array}{l}0.0368^{* * *} \\
(13.14)\end{array}$ & $66.91 \%$ & $\begin{array}{l}0.0648^{* * *} \\
(16.24)\end{array}$ & $91.65 \%$ & $\begin{array}{l}-0.0526 * * * \\
(-13.03)\end{array}$ & $82.19 \%$ \\
\hline Unexplained & $\begin{array}{l}-0.0273 * * \\
(-2.69)\end{array}$ & $30.85 \%$ & $\begin{array}{l}0.0181 * \\
(2.46)\end{array}$ & $33.09 \%$ & $\begin{array}{l}0.00589 \\
(0.54)\end{array}$ & $8.35 \%$ & $\begin{array}{l}-0.0114 \\
(-0.83)\end{array}$ & $17.81 \%$ \\
\hline$N$ & 8465 & & 78,893 & & 6038 & & 5883 & \\
\hline
\end{tabular}

$t$ statistics in parentheses

${ }^{*} p<0.05, * * p<0.01, * * * p<0.001$

endowments. Education explained $12.28 \%$ of the differences explained by endowments. A similar pattern is observed for Other race. The mean loss of employment income for Other race is higher from the population's mean loss of employment income by 0.106 or $10.6 \% .59 .06 \%$ of this difference is explained by differences in endowments, while $40.94 \%$ is unexplained by differences in endowments. Health insurance explained $30.83 \%$ of the differences explained by endowments, while income explained $29.87 \%$ of the differences explained by endowments. Health explained $17.41 \%$ of the differences explained by endowments, and education explained $16.457 \%$ of the differences explained by endowments. For Whites, income explained 23.9\%, health status explained $12.6 \%$, and health insurance explained $15.4 \%$. This trend is similar to what we obtained for Asians.

\section{Discussion}

The COVID-19 pandemic has destabilized both the US and global economy. However, its impact is much more than an economic impact. It has created high unemployment resulting from job or work loss in the economy. A look at the different ethnic groups shows that Other (Hispanics) and African Americans or Blacks were more likely to experience a work loss due to the COVID-19 pandemic than Whites and Asians. The mortality rate was also evident in confirming the disproportional impact of the COVID-19 pandemic on Other (Hispanics) and African American households. Our econometric analysis in Table 2 supports the results of our descriptive statistics.
Over the ongoing pandemic period, we have examined the loss of employment income in the USA with Household Pulse Survey data from August 19 to November 9, 2020. This constitutes 6 survey rounds merged. Except for week 18 data, this is mainly Phase 2 data. The results of our logistic regression showed a highly significant difference in the loss of employment income for Other (Hispanics) followed by Black households during this period. This result is consistent with both Pews Research findings and NPR, Robert Woodson Foundation, and Harvard University School of Public Health studies. Benitez et al. (2020) found that part of the disparities in COVID-19 outcomes can be explained by differences in long-run opportunity (income mobility and incarceration), human mobility, and demographics. Again, their findings are similar to our result that shows income to be highly significant in explaining the disparities in loss of employment income among the racial/ethnic groups.

We applied the Blinder-Oaxaca decomposition analysis to find the sources of the differences in loss of employment income between the races/ethnic groups. While income, education, health, access to computers and the Internet, and married status are significant in explaining the sources of difference for all races, about $30.8 \%$ of the differences in loss of employment income between Black households and the rest of the ethnic groups are unexplained. For Other households, $40.9 \%$ difference is unexplained. However, when we apply the survey weight, the figure for Blacks is $30.8 \%$, and $8.3 \%, 17.8 \%$, and $32.9 \%$ for Other, Asian, and Whites, respectively.

Anyamele (2015) concludes that discrimination accounted for $40.4 \%$ in loan delinquency between African 
Table 5 Blinder-Oaxaca detailed decomposition on loss of employment income on Household Pulse Survey

\begin{tabular}{|c|c|c|c|c|}
\hline & Black (1) & White (2) & Asian (3) & $\begin{array}{l}\text { Other (4) } \\
\text { Loss of employment }\end{array}$ \\
\hline \multicolumn{5}{|l|}{ Differential } \\
\hline Base group mean & $\begin{array}{l}0.431 * * * \\
(262.51)\end{array}$ & $\begin{array}{l}0.491 * * * \\
(140.20)\end{array}$ & $\begin{array}{l}0.442 * * * \\
(271.99)\end{array}$ & $\begin{array}{l}0.433 * * * \\
(267.18)\end{array}$ \\
\hline Analyzed group mean & $\begin{array}{l}0.526 * * * \\
(96.91)\end{array}$ & $\begin{array}{l}0.426 * * * \\
(242.08)\end{array}$ & $\begin{array}{l}0.395 * * * \\
(62.72)\end{array}$ & $\begin{array}{l}0.539 * * * \\
(82.99)\end{array}$ \\
\hline Difference & $\begin{array}{l}-0.0945 * * * \\
(-16.66)\end{array}$ & $\begin{array}{l}0.0647 * * * \\
(16.50)\end{array}$ & $\begin{array}{l}0.0479 * * * \\
(7.37)\end{array}$ & $\begin{array}{l}-0.106 * * * \\
(-15.85)\end{array}$ \\
\hline \multicolumn{5}{|l|}{ Explained } \\
\hline Income & $\begin{array}{l}-0.0304 * * * \\
(-20.22)\end{array}$ & $\begin{array}{l}0.0155^{* * *} \\
(19.17)\end{array}$ & $\begin{array}{l}0.0153 * * * \\
(16.74)\end{array}$ & $\begin{array}{l}-0.0187 * * * \\
(-17.72)\end{array}$ \\
\hline Education & $\begin{array}{l}-0.00851 * * * \\
(-13.94)\end{array}$ & $\begin{array}{l}0.00348 * * * \\
(11.14)\end{array}$ & $\begin{array}{l}0.0119 * * * \\
(14.99)\end{array}$ & $\begin{array}{l}-0.0103 * * * \\
(-13.97)\end{array}$ \\
\hline Health & $\begin{array}{l}-0.0124 * * * \\
(-17.41)\end{array}$ & $\begin{array}{l}0.00814 * * * \\
(17.01)\end{array}$ & $\begin{array}{l}0.00411^{* * * *} \\
(8.25)\end{array}$ & $\begin{array}{l}-0.0109 * * * \\
(-15.17)\end{array}$ \\
\hline Health insurance & $\begin{array}{l}-0.0172 * * * \\
(-17.05)\end{array}$ & $\begin{array}{l}0.00995^{* * * *} \\
(15.28)\end{array}$ & $\begin{array}{l}0.0139 * * * \\
(15.27)\end{array}$ & $\begin{array}{l}-0.0193 * * * \\
(-16.14)\end{array}$ \\
\hline Computer & $\begin{array}{l}-0.00106^{* * *} \\
(-3.72)\end{array}$ & $\begin{array}{l}0.000675 * * * \\
(3.73)\end{array}$ & $\begin{array}{l}0.000881 * * * \\
(3.70)\end{array}$ & $\begin{array}{l}-0.00139 * * * \\
(-3.73)\end{array}$ \\
\hline Internet & $\begin{array}{l}-0.00427 * * * \\
(-9.12)\end{array}$ & $\begin{array}{l}0.00291 * * * \\
(9.33)\end{array}$ & $\begin{array}{l}0.00310 * * * \\
(8.73)\end{array}$ & $\begin{array}{l}-0.00569 * * * \\
(-9.31)\end{array}$ \\
\hline Region & $\begin{array}{l}-0.000940 \\
(-1.21)\end{array}$ & $\begin{array}{l}0.000221 \\
(1.61)\end{array}$ & $\begin{array}{l}0.000438 \\
(1.85)\end{array}$ & $\begin{array}{l}0.00102 * \\
(2.30)\end{array}$ \\
\hline Marriage & $\begin{array}{l}0.00543 * * * \\
(4.26)\end{array}$ & $\begin{array}{l}-0.00294 * * * \\
(-4.40)\end{array}$ & $\begin{array}{l}-0.00138 * * * \\
(-3.61)\end{array}$ & $\begin{array}{l}0.00220^{* * * *} \\
(3.84)\end{array}$ \\
\hline Age cat & $\begin{array}{l}0.000105 \\
(1.54)\end{array}$ & $\begin{array}{l}-0.000186^{*} \\
(-2.53)\end{array}$ & $\begin{array}{l}-0.000283^{*} \\
(-2.55)\end{array}$ & $\begin{array}{l}0.000718^{* *} \\
(3.02)\end{array}$ \\
\hline School hours & $\begin{array}{l}-0.000841 * * * \\
(-4.60)\end{array}$ & $\begin{array}{l}0.000357 * * * \\
(3.42)\end{array}$ & $\begin{array}{l}0.000601 * * * \\
(3.45)\end{array}$ & $\begin{array}{l}-0.000482 * * \\
(-2.87)\end{array}$ \\
\hline Teaching hours & $\begin{array}{l}0.000423 \\
(1.80)\end{array}$ & $\begin{array}{l}-0.000224 \\
(-1.82)\end{array}$ & $\begin{array}{l}-0.0000716 \\
(-1.29)\end{array}$ & $\begin{array}{l}0.000124 \\
(1.51)\end{array}$ \\
\hline Week & $\begin{array}{l}0.000330 * * \\
(2.92)\end{array}$ & $\begin{array}{l}-0.000312 * * * \\
(-3.51)\end{array}$ & $\begin{array}{l}0.000424 * * \\
(3.12)\end{array}$ & $\begin{array}{l}0.00000141 \\
(0.01)\end{array}$ \\
\hline Total & $\begin{array}{l}-0.0693 * * * \\
(-30.21)\end{array}$ & $\begin{array}{l}0.0376^{* * * *} \\
(27.46)\end{array}$ & $\begin{array}{l}0.0490 * * * \\
(26.82)\end{array}$ & $\begin{array}{l}-0.0626 * * * \\
(-28.09)\end{array}$ \\
\hline \multicolumn{5}{|l|}{ Unexplained } \\
\hline Income & $\begin{array}{l}-0.0204 \\
(-1.46)\end{array}$ & $\begin{array}{l}-0.0278^{*} \\
(-2.49)\end{array}$ & $\begin{array}{l}0.104 * * * \\
(4.62)\end{array}$ & $\begin{array}{l}-0.0142 \\
(-0.80)\end{array}$ \\
\hline Education & $\begin{array}{l}0.0194 \\
(1.06)\end{array}$ & $\begin{array}{l}-0.0184 \\
(-1.35)\end{array}$ & $\begin{array}{l}0.0855^{* * *} \\
(2.84)\end{array}$ & $\begin{array}{l}-0.0553^{* *} \\
(-2.63)\end{array}$ \\
\hline Health & $\begin{array}{l}0.0175 \\
(1.18)\end{array}$ & $\begin{array}{l}-0.0168 \\
(-1.72)\end{array}$ & $\begin{array}{l}0.0228 \\
(1.51)\end{array}$ & $\begin{array}{l}0.00937 \\
(0.55)\end{array}$ \\
\hline Health insurance & $\begin{array}{l}-0.0371^{*} \\
(-2.17)\end{array}$ & $\begin{array}{l}0.00824 \\
(0.67)\end{array}$ & $\begin{array}{l}-0.0155 \\
(-0.69)\end{array}$ & $\begin{array}{l}0.0256 \\
(1.23)\end{array}$ \\
\hline Computer & $\begin{array}{l}-0.00258 \\
(-0.21)\end{array}$ & $\begin{array}{l}0.00788 \\
(0.87)\end{array}$ & $\begin{array}{l}-0.00366 \\
(-0.21)\end{array}$ & $\begin{array}{l}-0.0193 \\
(-1.25)\end{array}$ \\
\hline Internet & $\begin{array}{l}-0.00127 \\
(-0.10)\end{array}$ & $\begin{array}{l}-0.000972 \\
(-0.10)\end{array}$ & $\begin{array}{l}-0.0237 \\
(-1.24)\end{array}$ & $\begin{array}{l}0.0188 \\
(1.17)\end{array}$ \\
\hline Region & $\begin{array}{l}-0.0126 \\
(-0.86)\end{array}$ & $\begin{array}{l}0.0405^{* * * *} \\
(4.31)\end{array}$ & $\begin{array}{l}-0.0626 * * * \\
(-4.07)\end{array}$ & $\begin{array}{l}-0.0274 \\
(-1.52)\end{array}$ \\
\hline
\end{tabular}


Table 5 (continued)

\begin{tabular}{|c|c|c|c|c|}
\hline & Black (1) & White (2) & Asian (3) & Other (4) \\
\hline & Loss of employment & Loss of employment & Loss of employment & Loss of employment \\
\hline \multirow[t]{2}{*}{ Marriage } & 0.0175 & $-0.0121^{*}$ & -0.00195 & 0.0128 \\
\hline & $(1.87)$ & $(-2.09)$ & $(-0.22)$ & $(1.30)$ \\
\hline \multirow[t]{2}{*}{ Age cat } & $0.0509 *$ & -0.0254 & -0.0257 & 0.0158 \\
\hline & $(2.44)$ & $(-1.68)$ & $(-0.91)$ & $(0.64)$ \\
\hline \multirow[t]{2}{*}{ School hours } & -0.00782 & $0.0283 * *$ & $-0.0441^{*}$ & -0.0279 \\
\hline & $(-0.52)$ & $(2.61)$ & $(-2.42)$ & $(-1.49)$ \\
\hline \multirow[t]{2}{*}{ Teaching hours } & 0.00387 & 0.00159 & 0.00584 & -0.00672 \\
\hline & $(0.35)$ & $(0.21)$ & $(0.48)$ & $(-0.54)$ \\
\hline \multirow[t]{2}{*}{ Week } & -0.0129 & -0.0259 & $0.125^{*}$ & -0.0452 \\
\hline & $(-0.24)$ & $(-0.69)$ & $(2.04)$ & $(-0.70)$ \\
\hline \multirow[t]{2}{*}{ Constant } & -0.0397 & 0.0678 & -0.167 & 0.0702 \\
\hline & $(-0.58)$ & $(1.41)$ & $(-1.95)$ & $(0.86)$ \\
\hline \multirow[t]{2}{*}{ Total } & $-0.0252 * * *$ & $0.0271 * * *$ & -0.00111 & $-0.0435 * * *$ \\
\hline & $(-4.47)$ & $(7.12)$ & $(-0.18)$ & $(-6.63)$ \\
\hline$N$ & 8465 & 78,893 & 6038 & 5883 \\
\hline
\end{tabular}

$t$ statistics in parentheses

${ }^{*} p<0.05, * * p<0.01, * * * p<0.001$

Americans and Whites while $2.65 \%$ difference between Hispanics and Whites could be attributed to discrimination. Tharp et al. (2019) found a 19\% unadjusted pay gap in financial planning professionals based on gender. Cooray et al. (2014) found that discrimination accounted for $41 \%$ difference in academic rank between males and females. Anyamele (2018) found that $33.08 \%$ of the loan difference between African Americans and Whites during the financial crisis of 2008 is due to discrimination, while $7.3 \%$ of the differences between Hispanics and Whites were a result of discrimination.

\section{Conclusion and Policy Implications}

We have examined the loss of employment income on different ethnic/racial groups in the USA over the ongoing COVID-19 pandemic. Our study finds a highly statistically significant difference in the loss of employment income and expected loss of employment income among the races. Other and Blacks have a higher probability of experiencing loss of employment income and expected loss of employment income than Whites and Asians. The result from our study shows that women, regardless of race/ethnicity, had a much higher loss of employment income from the COVID-19 pandemic than men. Furthermore, we found that Black women had the highest loss of employment income than any other women. These findings are consistent with Pew Research (2020) and NPR, the Robert Woodson, and Harvard (2020).
Furthermore, our analysis showed that about $30 \%$ or more of this difference in loss of employment income is unexplained by differences in endowments or can be attributed to discrimination. We also found that income, health insurance, health status, education, access to computers, the Internet, and marital status were significant in explaining the differences among the races. While the US Congress passed the first CARES Act to reduce the adverse impact of the COVID-19 pandemic on US households, more specific actions are needed to address its disproportionate impact on Hispanic and African American households and women. The US Congress should focus on passing a minimum wage act, and skills acquisition legislature targeted to Blacks, Hispanics, Women, and lowincome households that will help in retraining the labor force while addressing the gap in income inequality.

\section{References}

Anyamele OD. Racial/ethnic differences in household loan delinquency rate. Rev Black Polit Econ. 2015. https://doi.org/10. 1007/s12114-015-9213-6.

Anyamele OD. Racial ethnic differences in household loan delinquency rate in recent financial crisis: evidence from 2007 and 2010 survey of consumer finances. Journal of Applied Finance and Banking. 2018;8(3):49-73.

Benitez J, Courtemanche C, Yelowitz A. Journal of Economics, Race, and Policy. 2020;3:243-61. https://doi.org/10.1007/ s41996-020-00068-9. 
Brinca P, Duarte JB, Faria e Castro M. Is the COVID-19 pandemic a supply or a demand shock? Economic Synopses. 2020;31. https:// doi.org/10.20955/es.2020.31.

Bureau of Labor Statistics. Labor force characteristics by race and ethnicity. Washington, DC: United States Department of Labor; 2015.

Bureau Of Labor Statistics. Impact of the coronavirus (COVID-19) pandemic on the employment situation for May 2020. 2020.

Centers for Disease Control and Prevention. COVID-19 in a long-term care facility - King County Washington. Morb Mortal Wkly Rep. 2020a;69(12):339-42.

Centers for Disease Control and Prevention. CDC health disparities and inequalities report - United States. MMWR: 60. 2013.

Centers for Disease Control and Prevention. Race, ethnicity, and age trends in persons who died from COVID-19 - United States. Morb Mortal Wkly Rep. 2020b;69(42):1517.

Chung-Bridges K, Muntaner C, Fleming LE, Lee DJ, Arheart KL, LeBlanc WG, ... Davila, EP. Occupational segregation as a determinant of US worker health. Am J Ind Med. 2008;51:555-567.

Commodari, E. The role of sociodemographic and psychological variables on risk perception of the Flu. SAGE Open: July-September, 1-10. 2017.

Cooray A, Verma R, Wright L. Does a gender disparity exist in academic rank? Evidence from an Australian university. Appl Econ. 2014;46(20):2441-51.

Cui J, Li F, Shi Z-L. Origin and evolution of pathogenic coronaviruses. Nat Rev Microbiol. 2019;17:181-92.

Deaton A. Policy implications of the gradient of health and wealth. Health Affairs. 2002;21(2):13-30.

Deaton A and Schreyer P. GDP, wellbeing, and health: thoughts on the 2017 round of the international comparison program. NBER Working Paper No. 28177. 2020.

Fairlie RW. An extension of the Blinder-Oaxaca decomposition technique to logit and probit models. J Econ Soc Meas. 2005;30(4):305-16.

Fairlie R. The impact of COVID-19 on small business owners: evidence from the first three months after widespread social-distancing restrictions. J Econ Manage Strat. 2020;29:727-40. https://doi. org/10.1111/jems. 12400 .

Fujishiro K, Heaney CA. "Doing what I do best": the association between skill utilization and employee health with healthy behavior as a mediator. Soc Sci Med. 2017;175:235-43.
Goolsbee A and Syverson C. Fear, lockdown, and diversion: comparing drivers of pandemic economic decline. NBER Working Paper No. 27432. 2020.

Jann B. The Blinder-Oaxaca decomposition for linear regression models. Stata J. 2008;8(4):453-79.

Kochhar R. Unemployment rose higher in three months of COVID-19 than it did in two years of the Great Recession. Pew Research Center. 2020.

Lau JT, Yang X, Tsui H, Kim JH. Monitoring community responses to the SARS epidemic in Hong Kong: from day 10 to day 62. J Epidemiol Community Health. 2003;57(11):864-70.

Liao Q, Cowling BJ, Lam WWT, Fielding R. Factors affecting intention to receive and self-reported receipt of 2009 pandemic (H1N1) vaccine in Hong Kong: a longitudinal study. PLoS ONE. 2011;6(3):e17713. https://doi.org/10.1371/journal.pone. 0017713 .

Mills CK, \& Battisto J. Double jeopardy: COVID-19's concentrated health and wealth effects in Black communities. Federal Reserve. 2020.

National Public Radio (NPR), The Robert Wood Foundation, and Harvard University T.H Chan School of Public Health. The impact of coronavirus on households, by race and ethnicity. Cambridge MA; 2020.

Nielsen HS. Discrimination and detailed decomposition in a logit model. Econ Lett. 1998;61(1):115-20.

Pew Research Center. Worries about coronavirus surge, as most Americans expect a recession - or worse. Pew Research Center. 2020.

Sinning M, Hahn M, Bauer TK. The Blinder-Oaxaca decomposition for nonlinear regression models. Stata J. 2008;8(4):480-92.

Tharp DT, Lurtz M, Mielitz KS, Kitces M, Ammerman DA. Examining the gender pay gap among financial planning professionals: a Blinder-Oaxaca decomposition. Financial Planning Review. 2019;2(3-4):e1061. https://doi.org/10.1002/cfp2.1061.

U.S. Census Bureau Household Pulse Survey August 19 through November 9, 2020.

U.S Department of Health and Human Services. CDC Health Disparities and Inequalities Report. 2013.

World Health Organization. MERS Situation Update. Cairo, Egypt: WHO - Eastern Mediterranean Regional Office(EMRO): Document No. WHO-EM/CSR/241/E. 2019.

Publisher's Note Springer Nature remains neutral with regard to jurisdictional claims in published maps and institutional affiliations. 